\title{
Modifikasi Minuman Fungsional 'Keloja' Berbasis Bahan Pangan Lokal sebagai Makanan Tambahan pada Anak Usia 24-59 Bulan
}

\section{Modification of 'Keloja' as a Functional Drink Based on Local Food as Additional Food in Children Age 24-59 Months}

\author{
Iskari Ngadiarti $^{1}$, Muntikah $^{2}$, Betty Yosephin Simanjutak ${ }^{3}$ \\ ${ }^{1,2}$ Jurusan Gizi, Politeknik Kesehatan Kemenkes Jakarta II, Indonesia \\ ${ }^{3}$ Jurusan Gizi, Politeknik Kesehatan Bengkulu, Indonesia
}

\section{ARTICLE INFO \\ Article history \\ Received date \\ 22 Jan 2021 \\ Revised date \\ 04 Feb 2021 \\ 05 Apr 2021 \\ Accepted date \\ 06 Apr 2021}

\section{Keywords:}

Corn;

Functional drink;

Moringa leaves;

Tolo beans.

\section{Kata kunci:}

Jagung;

Minuman fungsional;

Daun kelor;

Kacang tolo.

\author{
ABSTRACT/ ABSTRAK
}

One solution to overcome the problem of malnutrition in Indonesia is to provide nutritional interventions by adding micronutrient supplementation to food or beverages. This study aims to develop functional drinks from local food (Moringa leaves, tolo beans, and corn) as additional food ingredients for children aged 2-5 years. The first stage of the research carried out tolo bean germination, while in the second stage the study determined the formulation of a local food-based functional drink with four levels of treatment, namely $0 \%$ (T1), $5 \%$ (T2), $7.5 \%$ (T3), $10 \%$ (T4). ) Moringa leaves to total formula drinks. Organoleptic tests were carried out by 30 somewhat trained panelists from level 2 students of the DIII and DIV Nutrition study programs. Formulations that were acceptable to the panelists were the $\mathrm{T} 2$ formulation with a composition of $50 \%$ corn, $50 \%$ tolo beans, $5 \%$ Moringa leaves, $5 \%$ powdered milk, and $10 \%$ granulated sugar. The nutritional value of the tolo bean-based functional drink (T2) is $245,95 \mathrm{kcal}$ of energy, $8,57 \mathrm{gr}$ of protein, $5,25 \mathrm{gr}$ of fat, and $41,1 \mathrm{gr}$ of carbohydrates, and $458,71 \mathrm{ppm}$ of phenol content per $250 \mathrm{ml}$. With the addition of 5\%, Moringa leaves it produces color, aroma, taste, consistency, and acceptance that is most liked by panelists and resembles a drink without the addition of Moringa leaves. It is necessary to carry out further studies related to microbiological tests on functional drinks made from local food so that they can meet the applicable SNI.

\begin{abstract}
Salah satu solusi untuk mengatasi permasalahan malnutrisi di Indonesia yaitu memberikan intervensi gizi melalui penambahan suplementasi zat gizi mikro ke dalam makanan atau minuman. Penelitian ini bertujuan untuk mengenbangkan minuman fungsional dari pangan lokal (daun kelor, kacang tolo dan jagung) sebagai bahan makanan tambahan anak usia 2-5 tahun. Tahap pertama penelitian melakukan perkecambahan kacang tolo, sedangkan pada tahap kedua penelitian menentukan formulasi minuman fungsional berbasis pangan lokal dengan empat taraf pelakuan, yaitu $0 \%$ (T1), 5\% (T2), 7,5\% (T3), 10\%(T4) daun kelor terhadap total minuman formula. Uji organoleptik dilakukan oleh 30 panelis agak terlatih yang berasal dari mahasiswa tingkat 2 prodi DIII maupun DIV Gizi. Formulasi yang dapat diterima panelis adalah formulasi T2 dengan komposisi jagung 50\%, kacang tolo 50\%, daun kelor 5\%, susu bubuk 5\% dan gula pasir $10 \%$. Nilai gizi pada minuman fungsional berbasis kacang tolo (T2) yaitu energi sebesar 245,9 kkal, protein 8,57gr, lemak 5,25gr dan karbohidrat sebesar 41,1gr serta kandungan phenol $458,71 \mathrm{ppm}$ per $250 \mathrm{ml}$. Dengan penambahan $5 \%$ daun kelor menghasilkan warna, aroma, rasa, konsistensi dan daya terima yang paling disukai oleh panelis dan menyerupai minuman tanpa penambahan daun kelor. Perlu dilakukan kajian lebih lanjut terkait uji mikrobiologi pada minuman fungsional berbahan pangan lokal sehingga dapat memenuhi SNI yang berlaku.
\end{abstract}

Corresponding Author:

Iskari Ngardiarti

JurusanGizi, Politeknik Kesehatan Kemenkes Jakarta II, Indonesia

Email: iskaringardiarti@gmail.com 


\section{PENDAHULUAN}

Anak di bawah usia lima tahun (balita) adalah salah satu kelompok yang membutuhkan perhatian khusus karena retan terhadap gizi kurang. Kekurangan gizi terjadi karena ketidakseimbangan yang substansial antara kebutuhan energi dengan asupan yang diterima, sehingga menyebabkan kekurangan unsur zat gizi makro dan mikro secara kumulatif yang berdampak negatif pada pertumbuhan, perkembangan, dan aspek kesehatan lainnya. (Khairi \& Kanetro, 2012).

Gizi kurang dalam jangka waktu lama bisa berbahaya bagi tumbuh kembang balita karena dapat bersifat irreversibel, yang mana sulit untuk dipulihkan ke kondisi awal dan dapat menyebabkan terganggunya pertumbuhan fisik, gangguan mental, dan intelektual. Pertumbuhan pada fase ini relatif cepat sehingga membuaat anak membutuhkan nutrisi dalam jumlah yang relatif besar (Hoq, et al., 2019).

Faktor utama penyebab gizi kurang adalah asupan yang tidak adekuat dan adanya penyakit infeksi. Upaya yang perlu dilakukan adalah bagaimana meningkatkan asupan makanan sekaligus memberikan makanan yang mempunyai fungsi ganda sebagai sumber zat gizi dan mempunyai khasiat tambahan sebagai pencegah penyakit infeksi. Salah satu solusi untuk mengatasi permasalahan malnutrisi di Indonesia yaitu memberikan intervensi gizi seperti penambahan suplementasi zat gizi mikro ke dalam makanan atau minuman (Khaq, et al., 2018). Intervensi dalam bentuk minuman lebih disukai dan diterima oleh masyarakat serta memiliki daya terima yang lebih tinggi dibandingan makanan padat. Penelitian Ngadiarti (2017) memberikan F-100 (cair) atau F-100 modifikasi dengan tepung buatan lokal dapat mengatasi masalah malnutrisi akut pada anak baduta.

Dalam pembuatan minuman formula juga perlu dipertimbangkan bahan-bahan lokal yang terjangkau oleh semua kalangan sehingga mudah diaplikasikan oleh kehidupan masyarakat. Seperti halnya daun kelor, kacang tolo dan jagung yang merupakan tanaman yang mudah ditanam oleh masyarakat dengan harga yang terjangkau oleh semua kalangan.

Kelor (Moringa oleifera L.) masuk kedalam famili Moringaceae. Kelor merupakan tanaman yang memiliki daun, bunga, batang dan akar yang dipercaya memiliki zat antimikroba. Daun kelor mengandung 90 zat gizi alami seperti vitamin dan mineral, 46 antioksidan yang berfungsi sebagai penangkal radikal bebas, 36 senyawa anti inflamasi dan 18 asam amino yang diperlukan tubuh (Arissandi, et al., 2019). Sehingga membuat daun kelor menjadi suplemen makanan yang nyaris sempurna. Selain dijadikan bahan pengobatan, daun kelor juga sering dijadikan santapan sayuran seperti sayur bayam (Vergara-Jimenez, et al., 2017). Daun kelor dikenal mempunyai berbagai senyawa yang dapat menghambat pertumbuhan bakteri. Daun kelor diketahui mengandung senyawa fitokimia seperti flavonoid, saponin, dan tanin yang berperan sebagai antibakteri (Moyo, et al., 2012).

Kacang tolo dengan nama latin Vigna unguculata masuk ke dalam famili Fabaceae. Kacang tolo memiliki bentuk seperti kacang kedelai namun berwarna coklat. Kacang tolo mengandung tinggi protein dan karbohidrat dengan kandungan lemak relatif rendah dan pola asam amino komplementer dengan sereal menjadikan kacang tolo sebagai makanan bergizi (Jayathilake, et al., 2018). Kacang ini bahkan mengandung protein tertinggi kedua setelah kacang kedelai (Ismayanti \& Harijono, 2015). Namun, pemanfaatannya belum maksimal dan dipandang sebelah mata oleh sebagian orang. Kacang-kacangan sangat berperan dalam menyumbang protein dan zat gizi lain seperti kaya akan asam amino lisin yang diperlukan tubuh tapi kekurangan asam amino sulfur yaitu metionin. Kombinasi antara kacang tolo dengan serealia merupakan kombinasi yang sangat pas dengan menggabungkan asam amino lisin dengan asam amino metionin (Enyiukwu, et al., 2020).

Kelemahan dari kacang tolo adalah kandungan zat anti gizi seperti tannin, fitat, saponin dan alkalioid yang menghambat penyerapan zat gizi. Kandungan tannin dapat mengambat penyerapan protein, padahal protein adalah zat gizi utama yang didapat dari kacang tolo. Namun, hal ini dapat dikurangi dengan proses pengolahan seperti perendaman, perkecambahan dan fermentasi (Khairi \& Kanetro, 2012). Penelitian Vandana, et al. (2019) menyatakan bahwa suplementasi kacang tolo pada biskuit memberikan dampak yang signifikan terhadap perkembangan kognitif anak balita yang mengalami malnutrisi.

Berbeda dengan bahan pangan lokal daun kelor dan kacang tolo, jagung manis merupakan salah satu jenis serealia yang banyak dikonsumsi masyarakat selain beras. Jagung merupakan makanan pokok warga negara Indonesia bagian timur seperti daerah Nusa Tenggara Timur. Selain itu jagung mudah tumbuh diseluruh tanah Indonesia yang menyebabkan harga jagung dapat dijangkau oleh semua kalangan. Jagung manis mengandung $71 \%$ pati, $9,5 \%$ protein, $4,3 \%$ 
minyak, 1,4\% abu, dan 2,6\% gula. Jagung juga kaya akan asam amino palmitic, stearat, oleat, linoleat dan asam linoleat. Namun, jagung rendah akan asam amino lisin sehingga perpaduan antara jagung dengan kacang tolo dapat membuat kombinasi yang sempurna (Ignjatovic-Micic, et al., 2015). Rasa jagung yang manis disebabkan oleh tingginya kandungan gula di dalam jagung tersebut. Kandungan gula dalam jagung ini dapat dijadikan gula alami dalam sebuah produk sehingga dapat mengurangi bahkan mengganti penggunaan gula tebu atau gula buatan.Selain gula, jagung manis juga memiliki potensi lain, yaitu kandungan pigmen karotenoid. Menurut Alsuhendra, warna kuning pada jagung disebabkan oleh adanya karotenoid dengan kandungan berkisar antara $6,4-11,3 \mu \mathrm{g} / \mathrm{g}$. Sekitar 22\% diantaranya adalah $\beta$ karoten dan 51\% xantofil. Diketahui bahwa $\beta$ karoten merupakan senyawa yang memiliki aktivitas antioksidan dan provitamin A (Alsuhendra \& Ridawati, 2017).

Atas dasar tersebut peneliti tertarik untuk mengembangkan produk yang berbebahan dasar daun kelor, kacang tolo dan jagung sebagai minuman tambahan untuk anak usia 24-56 bulan. Tujuan dalam penelitian ini adalah mengembangkan, menganalisis uji organoleptik, menganalisa kandungan zat gizi, kadar proksimat dan kada phenol dalam minuman fungsional berbahan pangan lokal.

\section{METODE}

Tahapan penelitian meliputi penelitian pendahuluan, penelitian utama, uji organoleptik yang dilakukan di Laboratorium Ilmu Teknologi Pangan dan Laboratorium Uji Cita Rasa Jurusan Gizi Poltekkes Kemenkes Jakarta II. Pada penelitian pendahuluan meliputi penentuan konsentrasi daun kelor yang digunakan dalam pembuatan makanan tambahan untuk anak. Selanjutnya melakukan uji coba pembuatan produk jenis makanan tambahan yang sesuai dengan kriteria yang diinginkan yang tepat untuk sasaran. Selain itu juga pada penelitian tahap ini juga menentukan konsentrasi perbandingan penggunaan bahan dasar kacang tolo dengan jagung manis agar diperoleh minuman yang lebih lengkap kandungan zat gizi yang digunakan dalam formulasi produk ini. Sedangkan pada penelitian utama merupakan lanjutan dari penelitian pendahuluan yang telah diperoleh hasil yang sudah memenuhi kriteria yang sesuai dengan yang diharapkan. Pada penetitian utama dimulai dengan pembuatan produk minuman
KELOJA yang sesuai dengan hasil dari penelitian pendahuluan yang meliputi persiapan bahan, pembuatan produk minuman, melakukan uji organoleptik dan pengolahan data. Jenis penelitian ini adalah penelitian eksperimen dengan menggunakan 4 konsentrasi daun kelor, yang bertujuan untuk mengetahui formulasi minuman fungsional berbasis bahan pangan lokal (daun kelor, kacang tolo dan jagung) terhadap mutu organoleptik dan daya terima panelis.

Bahan yang digunakan untuk membuat produk minuman ini adalah kacang tolo kering jagung manis segar, daun kelor yang dipesan oleh pedagang sayuran, susu bubuk dan gula pasir semua bahan yang diperoleh dari pasar Mayestik Kebayoran Baru Jakarta Selatan, sedangkan alat yang digunakan pada pembuatan produk minuman ini meliputi alat untuk formulasi dan pembuatan produk yaitu kompor, blender, saringan, pisau, baskom, talenan, timbangan, panci, centong termometer air, dan kain kasa untuk menyaring.

Proses pembuatan minuman fungsional berbasis bahan pangan lokal untuk makanan tambahan anak usia 24-59 bulan adalah sebagai berikut:

1. Kacang tolo direndam semalam, cuci bersih lalu rebus dengan air : kacang tolo (1:2). masak sampai air habis dan kacang empuk.

2. Haluskan kacang tolo dengan menambahkan air matang (1:5), saring menggunakan kain kasa yang sudah di rebus terlebih dulu. Ukur filtrat yang diperoleh (ml).

3. Jagung manis segar dicuci dan bersihkan, kemudian disisir.

4. Timbang dan kukus selama 10 menit, blender tambahkan air masak 1:5, Saring dengan menggunakan kain kasa yang sudah direbus terlebih dulu kemudian filtrat di ukur volumenya $(\mathrm{ml})$.

5. Daun kelor dipilih timbang sesuai konsentrasi dan cuci bersih. Blensing pada suhu $85^{\circ} \mathrm{C}$ selama 3 menit. Lalu angkat dan masukkan dalam air es. Angkat dan tiriskan dengan cara keluarkan air dalam daun kelor.

6. Giling daun kelor dengan menggunakan filtrat salah satu jagung manis, kacang tolo atau campuran keduanya.

7. Saring daun kelor yang sudah dihaluskan dengan blender dan ukur volumenya.

8. Panaskan filtrat masukkan susu bubuk $5 \%$ dan gula pasir $10 \%$ tunggu sampai mencapai suhu $70^{\circ} \mathrm{c}$. Angkat dan dinginkan

9. Minuman siap untuk dikemas dan didinginkan dalam lemari es.

Selanjutnya melakukan uji organoleptik dengan panelis agak terlatih sebanyak 30 panelis. 
Panelis agak terlatih yaitu mahasiswa tingkat 2 prodi diploma 3 maupun prodi sarjana terapan gizi dan dietetika dengan alasan mahasiswa tersebut sudah mendapat mata kuliah tentang uji mutu organoleptik.

Analisis data hasil uji organoleptik yang meliputi warna, aroma, rasa dan tingkat kesukaan minuman fungsional berbasis bahan pangan lokal dianalisis secara deskriptif berdasarkan persentase, sedangkan kandungan zat gizi dianalisis dengan proximat. Analisis zat gizi proximat dilakukan di Laboratorium Saraswanti Bogor dan uji phenol dilakukan di Laboratorium Pengujian Balai Besar Penelitian dan Pengembangan Pasca Panen Pertanian IPB Bogor.

Penelitian ini sudah mendapatkan ethical clearance dari Pengkajian Etik Penelitian Kesehatan Poltekkes Kemenkes Jakarta II, No. LB.02.01/1/KE/31/490/2018 teranggal 23 Juli 2018.

\section{HASIL}

Faktor yang memengaruhi penerimaan suatu produk pangan pada dasarnya merupakan interaksi antara karakteristik produk dan persepsi individu terhadap produk. Persepsi individu dipengaruhi oleh karakteristik demografi, kebiasaan konsumen, dan preferensi individu. Karakteristik produk meliputi sifat fisik dan gizi produk serta sifat organoleptik produk yang merupakan faktor penting dalam penerimaan produk pangan yang baru dikembangkan (Profir, A.G., Vizireanu, 2013).

Analisis senosoris (uji organoleptik) merupakan instrumen penting yang dapat memberi informasi signifikan untuk pengembangan produk fungsional baru. Hasil analisis dapat memberikan pemahaman yang jelas tentang karakteristik produk dan dapat meningkatkan kepercayaan peneliti mengenai kualitas produk serta mengidentifikasi atribut sensori produk sesuai dengan prefensi konsumen (Profir, A.G., Vizireanu, 2013).

Uji organoleptik dilakukan pada 4 formula dan 3 kali replikasi. Pembuatan formulasi minuman fungsional ini dilakukan secara trial and error untuk menentukan formulasi yang secara organoleptik dapat disukai oleh konsumen. Komposisi minuman berbasis kacang tolo adalah kacang tolo $50 \%$, jagung manis $50 \%$, daun kelor $(0 \%, 5 \%, 7,5 \%$ dan $10 \%)$, susu bubuk $5 \%$ dan gula pasir $10 \%$.
Tabel 1. Hasil Persentase Penilaian Uji Organoleptik Panelis terhadap Warna Minuman Berbasis Kacang Tolo

\begin{tabular}{lrrrrrrrr}
\hline Kriteria & \multicolumn{2}{c}{ T1 } & \multicolumn{2}{c}{ T2 } & \multicolumn{2}{c}{ T3 } & \multicolumn{2}{c}{ T4 } \\
\cline { 2 - 8 } \multicolumn{1}{c}{ Warna } & n & \% & \multicolumn{1}{c}{ n } & \multicolumn{1}{c}{$\%$} & \multicolumn{1}{c}{ n } & \multicolumn{1}{c}{$\%$} & \multicolumn{1}{c}{ n } & \% \\
\hline Hijau gelap & 0 & 0 & 9 & 10 & 21 & 23,3 & 39 & 43,3 \\
Hijau tua & 0 & 0 & 60 & 66,7 & 57 & 63,3 & 45 & 50 \\
Hijau & 45 & 50 & 18 & 20 & 9 & 10 & 3 & 3,3 \\
Hijau muda & 45 & 50 & 3 & 3,3 & 3 & 3,3 & 3 & 3,3 \\
\hline
\end{tabular}

Berdasarkan Tabel 1 hasil persentase penilaian panelis terhadap warna minuman fungsional berbasis kacang tolo pada perlakuan T1 sebanyak 45 (50\%). Panelis memberikan penilaian yang sama dengan kriteria hijau dan hijau muda, pada perlakuan T2, T3 dan T4 masing-masing sebanyak 60 (66.7\%), 57 (63.3\%) dan $45(50 \%)$ panelis memberikan penilaian dengan kriteria yang sama berwarna hijau tua. Semakin tinggi konsentrasi penambahan daun kelor maka minuman berbasis kacang tolo yang dihasilkan semakin berwarna hijau tua.

Setelah dilakukan uji statistik Kruskal Walis dengan kepercayaan 95\% ( $p$-value $<0,05$ ) menunjukkan bahwa penambahan dau kelor pada minuman berbasis kacang tolo memberikan perbedaan warna yang signifikan ( $p$ value $=0,000$ ).

Tabel 2. Hasil Persentase Penilaian Uji Organoleptik Panelis terhadap Aroma Minuman Berbasis Kacang Tolo

\begin{tabular}{lrrrrrrrr}
\hline \multicolumn{1}{c}{ Kriteria } & \multicolumn{1}{c}{ T1 } & \multicolumn{2}{c}{ T2 } & \multicolumn{2}{c}{ T3 } & \multicolumn{2}{c}{ T4 } \\
\cline { 2 - 9 } \multicolumn{1}{c}{ Rasa } & n & \% & n & \% & n & \% & n & \multicolumn{1}{c}{} \\
\hline Sangat langu & 0 & 0 & 0 & 0 & 0 & 0 & 3 & 3 \\
Langu & 0 & 0 & 0 & 0 & 3 & 3 & 33 & 37 \\
Agak langu & 21 & 23 & 39 & 43 & 57 & 63 & 36 & 40 \\
Tidak langu & 69 & 77 & 51 & 57 & 30 & 34 & 18 & 20 \\
\hline
\end{tabular}

Dari hasil persentase penilaian pada Gambar 2 perlakuan T1 dan T2 masing-masing sebanyak $69(76,7 \%)$ dan $51(56,7 \%)$. Panelis menyatakan bahwa produk minuman berbasis kacang tolo yang dihasilkan panelis memberikan penilaian yang sama terhadap kriteria aroma tidak langu. Sedangkan pada perlakuan T3 dan T4 sebesar $57(63,3 \%)$ dan $36(40 \%)$ panelis memberikan penilaian dengan kriteria yang sama yaitu agak langu.

Setelah dilakukan uji statistik $p$ value $<0,05)$ menunjukkan bahwa penambahan dau kelor pada minuman berbasis kacang tolo memberikan perbedaan aroma yang signifikan ( $p$-value $=0,000)$. 
Tabel 3. Hasil Persentase Penilaian Uji Organoleptik Panelis terhadap Rasa Minuman Berbasis Kacang Tolo

\begin{tabular}{|c|c|c|c|c|c|c|c|c|}
\hline \multirow{2}{*}{$\begin{array}{c}\text { Kriteria } \\
\text { Rasa }\end{array}$} & \multicolumn{2}{|c|}{ T1 } & \multicolumn{2}{|c|}{ T2 } & \multicolumn{2}{|c|}{ T3 } & \multicolumn{2}{|c|}{ T4 } \\
\hline & $\mathbf{n}$ & $\%$ & $\mathbf{n}$ & $\%$ & $\mathbf{n}$ & $\%$ & $\mathbf{n}$ & $\%$ \\
\hline $\begin{array}{l}\text { Sangat } \\
\text { terasa }\end{array}$ & 0 & 0 & 0 & 0 & 0 & 0 & 5 & 6 \\
\hline Terasa & 0 & 0 & 15 & 17 & 3 & 3 & 31 & 34 \\
\hline Agak terasa & 18 & 20 & 24 & 27 & 57 & 64 & 36 & 40 \\
\hline Tidak terasa & 72 & 80 & 51 & 56 & 30 & 33 & 18 & 20 \\
\hline
\end{tabular}

Dari Tabel 3 penilaian panelis pada perlakuan T1 sebesar $72(80 \%)$ panelis memberikan penilaian produk minuman berbasis kacang toloyang dihasilkan dengan kriteria tidak terasa daun kelor. Pada perlakuan T2 dan T3 masing-masing sebesar $39(43,3 \%)$ dan 48 $(53,4 \%)$ panelis memberikan penilaian yang sama dengan kriteria agak terasa daun kelor. Sedangkan perlakuan T4 sebanyak $42(46,7 \%)$ panelis memberikan penilaian dengan kriteria terasa daun kelor.

Setelah dilakukan uji statistik Kruskal Walis dengan kepercayaan 95\% ( $p$-value $<0,05$ ) menunjukkan bahwa penambahan dau kelor pada minuman berbasis kacang tolo memberikan perbedaan rasa yang signifikan ( $p$-value $=0,000)$.

Tabel 4. Hasil Persentase Penilaian Uji Organoleptik Panelis terhadap Konsistensi Minuman Berbasis

\begin{tabular}{|c|c|c|c|c|c|c|c|c|}
\hline \multirow{2}{*}{$\begin{array}{c}\text { Kriteria } \\
\text { Rasa } \\
\end{array}$} & \multicolumn{2}{|c|}{ T1 } & \multicolumn{2}{|c|}{ T2 } & \multicolumn{2}{|c|}{ T3 } & \multicolumn{2}{|c|}{ T4 } \\
\hline & $\mathbf{N}$ & $\%$ & $\mathbf{N}$ & $\%$ & $\mathbf{N}$ & $\%$ & $\mathbf{N}$ & $\%$ \\
\hline Kental & 0 & 0 & 0 & 0 & $\bar{c}$ & 0 & 3 & 3 \\
\hline $\begin{array}{l}\text { Agak } \\
\text { kental }\end{array}$ & 0 & 0 & 6 & 7 & 21 & 23 & 21 & 23 \\
\hline Agak cair & 12 & 13 & 18 & 20 & 21 & 23 & 13 & 14 \\
\hline Cair & 78 & 87 & 66 & 73 & 48 & 54 & 53 & 60 \\
\hline
\end{tabular}

Berdasarkan Tabel 4 diketahui bahwa penilian panelis tertinggi terdapat pada perlakuan T1, T2, T3 dan T4 masing-masing sebanyak 78 (86.7\%), 66 (73.3\%), 48 (\%3.3\%), $54(60 \%)$ panelis memberikan penilaian dengan kriteria yang sama yaitu konsistensi minuman berbasis kacang tolo cair. Penambahan daun kelor semakin tinggi tidak memengaruhi konsistensi minuman minuman berbasis kacang tolo.

Setelah dilakukan uji statistik Kruskal Walis dengan kepercayaan 95\% ( $p$-value $<0,05$ ) menunjukkan bahwa penambahan dau kelor pada minuman berbasis kacang tolo memberikan perbedaan konsistensi yang signifikan ( $p$ value $=0,000$ ).
Tabel 5. Hasil Persentase Penilaian Uji Organoleptik Panelis terhadap Daya Terima Minuman Berbasis Kacang Tolo

\begin{tabular}{lrrrrrrrr}
\hline \multicolumn{1}{c}{ Kriteria } & \multicolumn{2}{c}{ T1 } & \multicolumn{2}{c}{ T2 } & \multicolumn{2}{c}{ T3 } & \multicolumn{2}{c}{ T4 } \\
\cline { 2 - 9 } \multicolumn{1}{c}{ Rasa } & n & \% & \multicolumn{1}{c}{ n } & \multicolumn{1}{c}{$\boldsymbol{\text { n }}$} & \multicolumn{1}{c}{$\boldsymbol{\%}$} & \multicolumn{2}{c}{ n } & \% \\
\hline Sangat suka & 18 & 20 & 3 & 3 & 0 & 0 & 0 & 0 \\
Suka & 60 & 67 & 57 & 63 & 54 & 60 & 30 & 33 \\
Kurang suka & 9 & 10 & 25 & 28 & 33 & 37 & 18 & 20 \\
Tidak suka & 3 & 3 & 5 & 6 & 3 & 3 & 42 & 47 \\
\hline
\end{tabular}

Dari Tabel 5 persentase penilaian panelis khusus untuk daya terima atau tingkat kesukaan jika kriteria suka dengan kriteria sangat suka digabung menjadi kriteria disukai. Hasil penilaian panelis terhadap daya terima produk minuman berbasis kacang tolo panelis memberikan penilaian dengan kriteria disukai pada perlakuan $\mathrm{T} 1, \mathrm{~T} 2, \mathrm{~T} 3$ dan $\mathrm{T} 4$ masingmasing sebesar 78 (86\%), 60 (66,7\%, 54 (60\%) dan $30(33,3 \%)$.

Setelah dilakukan uji statistik Kruskal Walis dengan kepercayaan 95\% ( $p$-value $<0,05$ ) menunjukkan bahwa penambahan dau kelor pada minuman berbasis kacang tolo memberikan perbedaan daya terima yang signifikan ( $p$ value $=0,000$ ).

Tabel 6. Analisis Zat Gizi Minuman Berbasis Kacang Tolo

\begin{tabular}{lr}
\hline Bahan & $\begin{array}{c}\text { Minuman berbasis } \\
\text { kacang tolo (T2) }\end{array}$ \\
\hline Jumlah & $100 \mathrm{ml}$ \\
Energi & $98,38 \mathrm{kkal}$ \\
Protein & $3,43 \mathrm{gr}$ \\
Lemak & $2,1 \mathrm{gr}$ \\
Karbohidrat & $16,44 \mathrm{gr}$ \\
Abu & $0,81 \%$ \\
\hline
\end{tabular}

Minuman berbasis kacang tolo dianalisis zat gizinya di laboratorium hanya pada formula yang disukai. Setelah dilakukan analisis nilai gizi minuman berbasis kacang tolo formula T2 dengan daun kelor sebesar 5\%, diketahui zat gizi dari minuman berbasis kacang tolo per $100 \mathrm{ml}$ dengan kandungan energi sebesar 98,38kkal, protein 3,43gr, lemak 2,10gr, karbohidrat 16,44gr. Adapun komposisi minuman berbasis kacang tolo yaitu daun kelor, kacang tolo, jagung, gula pasir, dan susu bubuk.

\section{PEMBAHASAN}

Minuman fungsional berbasis kacang tolo dan jagung dengan persentase penambahan daun kelor yang diberikan nama KELOJA. Dari hasil uji organoleptik didapatkan warna kesukaan 
panelis adalah warna hijau tua pada penambahan 5\% daun kelor (T2). Warna hijau pada minuman disebabkan oleh pigmen klorofil. Semakin tinggi konsentrasi daun kelor yang yang ditambahkan maka warna minuman akan semakin hijau tua sampai ke hijau gelap. Ini didukung hasil dari uji statistik non parametrik Kruskal Walis dengan nilai $p$-value $<0,05$ yang artinya terdapat pengaruh penambahan daun kelor terhadap warna minuman fungsional. Dari hasil tes uji lanjut Man Whitney diperoleh perbedaan nyata pada T1-T2, T1-T3 T1-T4 dan T2-T4.

Menurut Krisnadi (2015) kandungan pigmen klorofil tepung daun kelor adalah $162 \mathrm{mg}$ per $8 \mathrm{gr}$ bahan. Semakin tinggi proporsi daun kelor, maka warna minuman akan semakin gelap. Hal ini karena zat klorofil teroksidasi menjadi feofitin yang menyebabkan warna menjadi lebih gelap (Priyanto \& Nisa, 2016). Daun kelor mengandung 90 zat gizi alami seperti vitamin dan mineral, 46 antioksidan yang berfungsi sebagai penangkal radikal bebas, 36 senyawa anti inflamasi dan 18 asam amino yang diperlukan tubuh (Arissandi, et al., 2019).

Aroma yang paling banyak disukai oleh panelis terdapat pada formula T2 dengan penambahan daun kelor sebanyak 5\% yaitu aroma tidak langu. Semakin tinggi konsentrasi daun kelor yang ditambahkan pada minuman berbasis kacang tolo maka semakin meningkat aroma langu yang ditimbulkan pada minuman tersebut. Hal ini disebabkan karena reaksi enzim lipoksigenase yang terdapat dalam kacang tolo sehingga aktivitas enzim tersebut yang menyebabkan rasa langu (beany flavor) (Tunjungsari, 2019). Menurut Zakaria, et al daun kelor tidak banyak diolah sebagai pangan fungsional (Thamrin, et al., 2013). Dikarenakan rasanya yang langu sehingga daun kelor kurang digemari orang (Ismawati, 2016). Namun dengan penambahan $5 \%$ daun kelor pada formula ini menghasilkan aroma yang tidak langu dikarenakan sebelum diproses daun kelor dilakukan blanching terlebih dahulu untuk mengurangi aroma langu pada daun kelor. Blanching dapat berfungsi untuk menginaktifkan enzim yang berperan dalam proses kerusakan bahan pangan, dapat memperbaiki tekstur bahan, memperbaiki warna, mengurangi jumlah mikroorganisme dan dapat mempermudah proses pengolahan selanjutnya (Wulansari \& Sekar, 2017). Hal ini didukung hasil uji satistik non parametrik Kruskal Walis diperoleh hasil $p$ value $<0,05$ yang artinya ada pengaruh penambahan daun kelor dengan konsentrasi yang berbeda terhadap aroma minuman fungsional berbasis bahan lokal. Dari hasil uji lanjut terdapat perbedaan yang yata pada perlakuan T1-T3, T1T4, T2-T3, T2-T4 dan T3-T4 dengan masingmasing nilai $p$-value $=0,000$.

Rasa yang paling disukai oleh panelis yaitu pada formula T2 dengan penambahan 5\% daun kelor menghasilkan minuman fungsional yang tidak terasa daun kelor. Rasa pada minuman dengan penambahan konsentrasi daun kelor yang berbeda menghasilkan rasa yang berbeda. Semakin tinggi persentase penambahan daun kelor akan mempertajam rasa minuman fungsional tersebut. Hal ini didukung hasil uji sttistik non parametrik Kruskal Wallis diperoleh hasil $p$-value $<0,05$ yang artinya ada pengaruh penambahan daun kelor dengan konsentrasi yang berbeda terhadap rasa minuman fungsional berbasis bahan lokal. Hal tersebut disebabkan oleh karena daun kelor memiliki rasa yang khas yaitu rasa pahit, getir dan pedas (Purba, 2020). Hasil uji lanjut terdapat perbedaan yang nyata pada perlakuan T1-T2, T1-T3, T1-T4, T2-T4 dan T3-T4 dengan masing-masing nilai $p$ value $=0,000$.

Konsistensi minuman fungsional yang paling banyak disukai oleh panelis adalah formula T2 dengan penambahan 5\% daun kelor menghasilkan konsistensi cair. Konsistensi minuman ini sesuai dengan SNI minuman yaitu dengan konsistensi cair. Semakin tinggi konsentrasi penambahan atau penggunaan daun kelor hasil penilaian panelis terhadap konsistensi minuman semakin menurun. Hal ini didukung hasil uji statistik non parametrik Kruskal Wallis diperoleh hasil $p$-value $<0,05$ yang artinya ada pengaruh penambahan daun kelor dengan konsentrasi yang berbeda terhadap konsistensi minuman fungsional berbasis bahan lokal. Dari hasil uji lanjut terdapat perbedaan yang yata pada perlakuan T1-T3, T1-T4, T2-T3, T2-T4 dan T3T4.

Dari hasil Tabel 5 penilaian daya terima panelis terhadap minuman fungsional berbasis bahan lokal dengan penggunaan daun kelor 5\% mendapat penilaian tertinggi dengan kriteria suka dan sangat suka digabung sebesar $60(63,3 \%)$, panelis, dan semakin tinggi penggunakan daun kelor penilaian panelis semakin menurun yaitu dengan kriteria agak suka. Hal ini didukung hasil uji statistik non parametrik firedman daya terima diperoleh hasil $p$-value $<0,05$ yang artinya ada pengaruh penambahan daun kelor dengan konsentrasi yang berbeda terhadap daya terima minuman fungsional berbasis bahan lokal. Dari hasil uji lanjut terdapat perbedaan yang yata pada perlakuan T1-T2, T1-T3, T1-T4, T2-T4 dan T3T4. Sehingga dapat disimpulkan bahwa formula T2 merupakan pilihan panelis terbanyak sehingga 
di analisis kandungan zat gizi di laboratorium. Produk minuman fungsional berbasis kacang tolo sebanyak $250 \mathrm{ml}$ hari yaitu dengan kandungan gizi sebesar energi $245,95 \mathrm{kkal}$, protein $8,57 \mathrm{gr}$, lemak 5,25gr, dan karbohidrat 41,1gr. Kandungan phenol yang terkandung pada minuman berbasis kacang tolo sebesar $458,71 \mathrm{ppm}$.

\section{SIMPULAN}

Kandungan zat gizi minuman fungsional berbasis pangan lokal (berbahan dasar daun

\section{DAFTAR PUSTAKA}

Alsuhendra, \& Ridawati. (2017). Pelatihan Diversifikasi Produk Olahan Jagung Manis pada Tutor Pendidikan Anak Usia Dini di Kecamatan Makasar , Jakarta Timur (Training Diversifying Sweet Corn Products for the Early Chilhood Education Tutor in Makasar Subdistrict , East Jakarta). Agrokreatif, 3(November), 100107.

Arissandi, D., Setiawan, christina T., \& Wiludjeng, R. (2019). Efektifitas Ekstrak Kelor (Moringa oleifera lamk) Terhadap Pertumbuhan Jamur Candida albicans. Jurnal Borneo Cendekia, 3(2), 40-46.

Enyiukwu, D. N., Chukwu, L. A., \& Bassey, I. N. (2020). Nutrient and anti-nutrient compositions of cowpea ( Vigna unguiculata) and mung bean (Vigna radiata) seeds grown in humid Southeast Nigeria: A comparison. 4(2), 41-45. https://doi.org/10.13057/tropdrylands/t040 202

Hoq, M., Ali, M., Islam, A., \& Banerjee, C. (2019). Risk factors of acute malnutrition among children aged 6-9 months enrolled in a community-based programme in Kurigram, Bangladesh : a mixed-method matched case-control study. Journal of Health, Population and Nutrition, 2, 1-7.

Ignjatovic-Micic, D., Vancetovic, J., Trbovic, D., Dumanovic, Z., Kostadinovic, M., \& Bozinovic, S. (2015). Grain nutrient composition of maize (Zea mays L.) drought-tolerant populations. Journal of Agricultural and Food Chemistry, 63(4), 1251-1260.

https://doi.org/10.1021/jf504301u

Ismawati, R. (2016). Studi Tentang Tingkat Kesukaan Responden Terhadap kelor, kacang tolo, dan jagung) dalam $250 \mathrm{ml} / \mathrm{sajian}$ yaitu energi $245,95 \mathrm{kkal}$, protein $8,57 \mathrm{gr}$, lemak 5,25gr, dan karbohidrat 41,1gr. Kandungan phenol pada minuman berbasis kacang tolo yaitu 458,71ppm. Minuman fungsional berbasis pangan lokal dengan substitusi daun kelor sebesar 5\% memberikan warna, aroma, rasa, tektur, konsentrasi dan daya terima yang paling disukai oleh panelis. Perlu dilakukan kajian lebih lanjut terkait uji mikrobiologi pada minuman fungsional berbahan pangan lokal sehingga dapat memenuhi SNI yang berlaku.

Penganekaragaman Lauk Pauk Daun Kelor (Moringa oleivera). E-Jurnal Boga, 5(1), 17-22.

Ismayanti, M., \& Harijono. (2015). Formulation of Complementary Feeding Based on Germinated Cowpea Flour and Corn Using Linear Programming. Jurnal Pangan Dan Agroindustri, 3(3), 996-1005.

Jayathilake, C., Visvanathan, R., Deen, A., Bangamuwage, R., Jayawardhana, B. C., Nammi, S., \& Liyanage, R. (2018). Cowpea: an overview on its nutritional fact and health benefits. Journal of the Science of Food and Agriculture, 98(13), 47934806.

https://onlinelibrary.wiley.com/doi/epdf/10 $.1002 /$ jsfa. 9074

Khairi, E., \& Kanetro, B. (2012). Pengaruh Berbagai Kecambah Kacang-kacangan Terhadap Kadar Protein Terlarut dan Asam Amino Bebas Limbah Cair Isolasi Protein. AgriSains, 5(2), 102-114.

Khaq, A. E., Yuniastuti, A., \& Rahayu, S. R. (2018). An Analysis of Picky Eater Towards Growth and Motor Development at Kebasen District Health Centre. Public Health Perspective Journal, 3(3), 224-230.

Krisnadi, A. D. (2015). Kelor Super Nutrisi. Edisi Revisi Maret 2015. Lembaga Swadaya Masyarakat-Media Peduli Lingkungan (LSM-MEPELING).

Moyo, B., Masika, P. J., \& Muchenje, V. (2012). Antimicrobial activities of Moringa oleifera Lam leaf extracts. African Journal of Biotechnology, 11(11), 2797-2802.

Ngadiarti, I., Simanjuntak, B. Y., Anwar, I., \& Srimiati, M. (2017). Formula F-100 Based Complementary Feeding and Locally Made Flour to Underweight Toddlers. 
Asian Journal of Clinical Nutrition, 9(4), 147-154.

https://doi.org/10.3923/ajen.2017.147.154

Priyanto, A., \& Nisa, F. C. (2016). Formulation of Moringa leaves and by-product of green grass jelly as Composite Flours in Noodle Making. Jurnal Teknologi Pertanian, 17(1),

https://doi.org/10.21776/ub.jtp.2016.017.0 1.4

Profir, A.G., Vizireanu, C. (2013). Sensorial Analysis of a Functional Beverage Based on Vegetables Juice. Acta Biologica Szegediensis, 57(2), 145-148. https://doi.org/10.17728/jatp.6150

Purba, E. C. (2020). Kelor (Moringa oleifera Lam.): Pemanfaatan dan Bioaktivitas. ProLife, $7(1)$,

$1-12$. https://doi.org/10.33541/jpvol6iss2pp102

Thamrin, A., Lestari, R. S., \& Hartono, R. (2013). Pemanfaatan Tepung Kelor (Moringa oleifera) dalam Formulasi Pembuatan Makanan Tambahan untuk Balita Gizi Kurang. Media Gizi Pangan,
$X V(1), 1-6$.

Tunjungsari, P. (2019). Pengaruh Penggunaan Tepung Kacang Tunggak (Vigna Unguiculata) Terhadap Kualitas Organoleptik Dan Kandungan Gizi Biskuit. TEKNOBUGA: Jurnal Teknologi Busana Dan Boga, 7(2), 110-118.

Vandana, Preeti, \& Kushwaha, A. (2019). Study of Effect of Cowpea Biscuits Supplementation on Nutritional and Cognitive Development of Malnourished Pre-school Children. Current Journal of Applied Science and Technology, 37(3), 1-10. https://doi.org/10.9734/cjast/2019/v37i330288

Vergara-Jimenez, M., Almatrafi, M. M., \& Fernandez, M. L. (2017). Bioactive components in Moringa oleifera leaves protect against chronic disease. Antioxidants, 6(4), 1-13. https://doi.org/10.3390/antiox6040091

Wulansari, A., \& Sekar, N. (2017). Blanching. Laporan Praktikum Teknologi Pengolahan Pangan. Purwokerto: Fakultas Pertanian, Universitas Jenderal Soedirman. 